\title{
Gerard of Nazareth, John Bale and the Origins of the Carmelite Order
}

\author{
by ANDREW JOTISCHKY
}

$\mathrm{D}$ escribing the general condition of the Latin Church in Outremer in the I 220s, Jacques de Vitry enumerated, as examples of those who had chosen the religious life, the hermits of Mt Carmel:

Others, following the example and imitation of the holy solitary Elijah the Prophet, live on Mt Carmel, especially on the part which overlooks the city of Porphyria, which today is called Cayphas [Haifa], near the spring which is called the spring of Elijah, and not far from the monastery of the Blessed Virgin Margaret. They lead a solitary life in small cells as in a hive; like the bees of the Lord they gather the honey of spiritual sweetness. ${ }^{1}$

The phenomenon of eremitical monasticism in western Europe in the eleventh and twelfth centuries has been studied extensively, ${ }^{2}$ but little material has been found that might shed light on the foundation of eremitical communities by Franks in the Latin East. In 1983 , however, Benjamin Kedar rescued from obscurity the surviving fragments of the $D_{e}$ conversatione servorum Dei, a compilation of biographies of contemporary hermits and monks by the twelfth-century bishop of Laodicea, Gerard of Nazareth, who had himself been a hermit and a Benedictine monk. Gerard's work had been known earlier only in selected abbreviated portions in the compendium of church history published by the Centuriators of Magdeburg in Basle between 1562 and $1574 .^{3}$

1 Jacques de Vitry, 'Historia Hierosolymitana', LII, in J. Bongars (ed.), Gesta Dei per Francos, Hanau i61 I, i. 1075.

${ }^{2}$ See for example Jean Leclercq, 'La crise du monachisme aux xie et xiie siècles', Bullettino dell'Insitituto storico Italiano per il medio evo lxx (1958), 19-41, Derek Baker, 'Crossroads and crises in the religious life of the later eleventh century', in idem (ed.), The Church in the town and countryside (Studies in Church History xvi, 1979), 137-48, and especially Henrietta Leyser, Hermits and the new monasticism, New York 1984 .

${ }^{3}$ B. Z. Kedar, 'Gerard of Nazareth, a neglected twelfth-century writer of the Latin East: a contribution to the intellectual history of the Crusader States', Dumbarton Oaks Papers xxxvii (1983), 55-77; Matthias Flacius Illyricus and others, Duodecima centuria (vol. vi of Ecclesiasticae historiae, integram Ecclesiae Christi ideam... secundam singulas centurias perspicuo ordine complectens, 7 vols, Basle ${ }_{15}^{62-74)}$. 
Despite its fragmentary survival, Gerard's De conversatione is, as Kedar has shown, important evidence both for the intellectual activity of a Latin bishop in twelfth-century Syria and for the character of Latin monastic foundations in Outremer. Besides the De conversatione, Gerard is also known to have written a separate life of Elias of Narbonne, abbot of Palmaria in Galilee, a sermon to the nuns of St Lazarus in Bethany, a treatise on the identity of Mary Magdalene contra Graecos, and a defence of his views on this subject against a priest called Sala, fragments of which were also preserved by the Centuriators. ${ }^{4}$ This output suggests that William of Tyre was not unique among Latin bishops of Outremer for his intellectual endeavours. The De conversatione and Vita abbatis Eliae are particularly valuable. Although some cartularies from the great Latin monasteries of the Crusader States survive, ${ }^{5}$ there is very little extant narrative material relating to the general condition of monasteries or the nature of the monastic settlement in the Holy Land. The biographies in the De conversatione are, in most cases, no more than character sketches of monks and hermits Gerard knew personally or by reputation between c. I I 20 and $c$. I 60 , but they provide engrossing details about the types of monasteries being founded in the second and third generations of the Frankish conquest, and about the individual enterprises of men drawn to the monastic life in the Holy Land. The religious life of the Crusader States can thus be fitted into the context of the monastic reform movement of the late eleventh and twelfth centuries in the west. ${ }^{6}$

The fragments of the De conversatione preserved by the Centuriators do not quite represent the total extent of our knowledge of Gerard. Kedar found a further passage of the De conversatione cited in three fourteenthcentury treatises by Carmelite monks: Philip Ribot's De institutione et peculiaribus gestis religiosorum Carmelitarum (c. I370), the Informatio circa originem, institutionem et confirmationem Ordinis Fratrum Beatae Virginis Mariae de Monte Carmelo of Bernard Ollerius ( $f$. $1375-83$ ) and the Dyalogus inter directorem et detractorem de ordine Carmelitarum of John of Hildesheim (d. I 375). ${ }^{7}$ The use of Gerard's work by Carmelite apologists raises important questions about the self-perception of the order. By introducing further evidence of the use of Gerard of Nazareth by a Carmelite with proven connections with the Centuriators of Magdeburg, the sixteenth-century

4 Ibid. 923, 1 230-3, 1380, 1603; edited by Kedar, 'Gerard of Nazareth', 75-7.

s For example Le cartulaire du Saint-Sépulchre, ed. G. Bresc-Bautier, Paris 1984; Chartes de Terre-Sainte provenant de l'abbaye de Notre-Dame de Josaphat, ed. H.-F. Delaborde, Paris 1880 ; Chartes de l'abbaye de Mont-Sion, ed. E.-G. Rey (Mémoires de la Société Nationale des Antiquaires de France 5 th ser. viii, 1899 ).

6 See A. T. Jotischky, 'The breath of the dove: hermits and eremitical monasticism in the Holy Land I095-129I', unpubl. PhD diss. Yale I991, I6-63.

7 These works are most accessible in the editions of Daniel a Virgine Maria, in his collection Speculum Carmelitanum, 4 pts, Antwerp I68o, pt I, I-128, pt II, 145-56, I66-7ı. The treatise Contra Salam presbyterum is corroborated by a mention in an independent source, the Defensorium of the Carmelite John Hornby against the Dominican John Stokes: Oxford, Bodleian Library, ms e Musaeo 86, fo. 202r. 
English antiquarian and polemicist John Bale, I hope in this article to clarify some of the problems in Carmelite historiography, and to show how apparently untrustworthy material can be used to further our knowledge of eremitical monasticism in the Latin East.

The historical accounts presented by Carmelite authors were informed by a specific agenda. Primarily, they wanted to establish credible evidence for the foundation of the order by Elijah and the unbroken continuity of an eremitical settlement on Mt Carmel from the 'minor prophets' and their chosen successors until their conversion to Christianity by the apostles and the influx of new hermits in the fourth century. Occupation of Mt Carmel by hermits following the same tradition was held to have continued until the fall of the Crusader Kingdom in $129 \mathrm{I}$, by which time the hermits had expanded beyond their original site to settle all over Europe. ${ }^{8}$ There is no contemporary evidence for such a coherent settlement for any period before the beginning of the thirteenth century. The Carmelite Order was recognised by Pope Honorius III in 1226, with the confirmation of the Rule that had been written for a group of hermits on Mt Carmel by Albert of Vercelli, patriarch of Jerusalem (I 205-I4). The reform of the Rule of St Albert in 1 248, endorsed by Pope Innocent Iv, allowed the Carmelites to practise a mendicant rather than eremitical profession. ${ }^{9}$ The apologies of Carmelite historians, especially Ribot, were written to counter the hostility encountered by Carmelites from the I 240 S onward (the period of expansion into Europe) at the hands of the episcopal hierarchy and the rival mendicant orders. The most significant aspect of the Carmelite historical claims was thus the attempt to prove that the original 'Carmelites' of the Old Testament and early Christian periods had followed a way of life inspired by the career of Elijah, who was both a solitary hermit and a preacher, and that the modifications to the Rule represented the profession of the original Carmelites more closely than the simple rule of St Albert. ${ }^{10}$

The twelfth-century origins of the Carmelite Order are still entangled in the web woven by Ribot, and other Carmelite historians from the fourteenth century to the present day. Modern scholars have been deterred by the historiographical problems implicit in a study of the Carmelite foundation. The earliest surviving accounts from within the order were written 150 years after the papal confirmation of the order in I 226, and must be understood in the context of the course of Carmelite settlements in Europe. In I 374, at roughly the time that Ribot, Bernard and John of Hildesheim were writing, a debate was held between a

${ }^{8}$ No scholarly study has yet been written on the transformation of the hermits of $\mathrm{Mt}$ Carmel into an international order of friars. For an introduction to the topic, see Jotischky, 'Breath of the dove', 2 I4-97. The origins of the foundation on Mt Carmel have been studied by Elias Friedman, The Latin hermits of Mount Carmel, Rome 1979. For the Carmelite settlement in England, see K. J. Egan, 'An essay toward the historiography of the origin of the Carmelite Province in England', Carmelus xix (1972), 67-100.

${ }^{\theta}$ Les registres d' Innocent IV, ed. E. Berger, Paris $188_{4}-\mathrm{I} 92 \mathrm{I}$, i, nos $3287-8$.

10 Ribot, De institutione, passim. 
Carmelite and a Dominican doctor of theology at the University of Cambridge on the antiquity of the Carmelite Order: the Dominican derided the Carmelites as newcomers, while the Carmelite maintained the Elianic foundation of the order and the continuous presence on Mt Carmel until I29I. The chancellor of the university awarded the debate to the Carmelite. ${ }^{11}$ That such a matter was a fit subject for academic debate reveals something of the suspicions of rival orders about the Carmelites' own account of their origins. St Francis and St Dominic were well-documented figures about whom contemporary or near-contemporary accounts survived, but the Carmelites were still, more than a hundred years after their appearance in England, an unknown quantity. They had no charismatic founder for whom miracles could be claimed, and they came from a land long since lost to Christendom. Their claims to possess a Rule composed in the fifth century and updated in the twelfth, and thus to be an older order than the pre-eminent mendicants, the Franciscans and Dominicans, seemed highly contentious. Ribot and his followers were writing to counter such suspicions. A parallel to the Cambridge debate, the Dyalogus of John of Hildesheim, shows a Carmelite friar turning the objections of a detractor (who appears to be a friar of another order) into an opportunity to expound the Carmelite view of Old Testament and early Christian history.

A more direct connection can now be established between the work of Carmelite apologists and the Centuriators who preserved Gerard of Nazareth's De conversatione through the person of John Bale, and by extension also between Gerard of Nazareth and his hermits and the origins of the Carmelite Order. A manuscript at Oxford in the hand of John Bale, who was prior of the Carmelite house at Norwich before going over to the Reformation in I533, includes a treatise on the chronology of the Carmelite Order which also mentions Gerard of Nazareth and lists the hermits who formed the subjects of the De conversatione servorum Dei. ${ }^{12}$ The treatise, entitled Cronica seu fascicula temporum ordinis Carmelitarum, is part of a collection of miscellaneous Carmelite material, mostly historical or apologetical, either copied or edited by Bale out of other sources. Bale's biographer, L. P. Fairfield, called it 'a systematic collection of notes, the spadework for a full-scale history of the Carmelite Order'. ${ }^{13}$ Bale himself disclaims the originality of the Cronica, supplying as sources the names of the Carmelite authors Giles Faber, Laurence Burellus, John Paleonydorous, Arnold Bostius, Nicholas Harlemensis and Julian Basart. The Cronica thus reflects existing Carmelite traditions about the order's origins

11 Cambridge UL, MS Ff 6, 11 , fo. $27 \mathrm{v}-\mathrm{r}$, summarised in Arnold Bostius's De illustribus viris ordinis fratrum beatissime virginis Marie de monte Carmelo, ed. C. Jackson-Holzberg, Zwei Literaturgeschichlen des Karmelitenordens, Erlangen 1981, I 54-5. The defence of the Carmelite, John Hornby, was later copied into the collection known as Fasciculi Zizianorum, Oxford, Bodl. Lib., Ms e Musaeo 86, fos $176 \mathrm{v}-2$ I Ir.

12 Bodl. Lib., ms Selden Supra 41, fos $107 \mathrm{r}-96 \mathrm{r}$.

${ }^{13}$ L. P. Fairfield, John Bale: mythmaker for the English Reformation, West Lafayette 1976 , 28. 
rather than creating them. It was written between $c$. I 527 and I 533 , but Bale returned to the Cronica after his conversion to write a further two pages that are distinctly Protestant in tone. ${ }^{14}$ In any case, the material relating to Gerard of Nazareth was compiled about thirty years before the publication of the first volume of the Centuriators' Ecclesiasticae historiae.

Bale's Cronica follows the tradition of Carmelite history-writing, of which Philip Ribot was the most sophisticated exponent, by attempting to establish, on the basis of existing sources, a 'Carmelite genealogy', beginning with Elijah and ending with the priors-general of his own day. The Cronica is less a history than a catalogue of individual Carmelite 'Fathers'. Each such figure Bale placed in a red circle, accompanied by a few words, a date and sometimes a longer supplementary passage of historical notes. The 'genealogy' is thus an ecclesiastical counterpart to the genealogical rolls of kings, but in book rather than roll form. Lesser figures, or events with only an incidental connection to the development of the order, are placed on the bottom half of each page. Gerard of Nazareth and the list of his hermits merit almost a page of these notes for the mid twelfth century. He is not claimed specifically by Bale as a Carmelite 'father', but as someone associated with the growth of the order, at a time when, as we shall see, independent evidence for eremitical settlement on Mt Carmel is just beginning.

No manuscripts of Gerard's De conversatione are known to survive; it is therefore impossible to know for certain the source of either Bale's or the Centuriators' knowledge of his material. Bale's works, however, have been studied so comprehensively by scholars of the Reformation that it is possible to reconstruct his archival research in the years before 1533 from four of his own manuscript notebooks. John Bale was born in Suffolk in I 495 and had entered the Carmelite convent at Norwich by 1507 . Between $15^{14}$ and 1523 he was a student at Cambridge, during which period he was ordained to the diaconate; in the $15^{20 s}$ he was ordained priest and continued his studies, spending in addition a good deal of time researching Carmelite history in the libraries of various houses of the order in England, France and the Low Countries. ${ }^{15}$ The earliest manuscripts in his hand reflect this conventional pattern; Cambridge UL, Ms Ff. 6. 28 is a collection of saints' lives and Carmelite offices made while Bale was a student, between I5I4 and I523, and Oxford, Bodleian Library, Ms Selden Supra 72 is a set of scribal exercises set by Bale for younger students, probably while he was himself an advanced student in the Carmelite house at Cambridge. ${ }^{16}$ Neither manuscript contains material relating to

14 Ibid. I60-I. The full discussion on the dating of Bale's manuscripts is on pp. $157-64$. See also the chronological list of Bale's works compiled by W. T. Davies: 'A bibliography of John Bale' (Oxford Bibliographical Society Proceedings and Papers v, 1936-9), 203-79 at pp. $240^{-}-3$.

15 Fairfield, John Bale, 1-15.

${ }_{16}$ Ibid. 8, for Bale as the instructor of younger students. Selden Supra 72 includes a list of Carmelite priors-general and extracts copied from the works of two earlier Norfolk Carmelites, John Baconthorpe and Robert Bale. 
Gerard of Nazareth. The next two manuscripts in Bale's hand consist of notebooks compiled during his research trips in the years between $1522-3$ and 1528: Oxford, Bodl. Lib., Ms Bodley 73 was made primarily in England and the Low Countries, and BL, Ms Harley 1819 in England and France. ${ }^{17}$ The material in both is a miscellany of notes on Carmelite history, extracts from treatises, some of which were presumably unavailable in English Carmelite libraries, and catalogues of notable Carmelite friars, such as a list of those Carmelites who had taken a higher degree in theology in Paris. There is little internal coherence to these notebooks, and no attempt to organise the material according to archival principles, but marginal entries are used to indicate the house where Bale read and noted specific works, making it possible to retrace his research itinerary. In neither of these notebooks, however, does he record his reading of Gerard of Nazareth's De conversatione or any work mentioning or paraphrasing it. There is thus no trace of Gerard in any of Bale's reading before his appearance in the Cronica in Selden Supra $4^{1}$ between I 527 and I533. It may be assumed either that he had heard or read of Gerard as a boy in the Norwich convent, and that Gerard had become so deeply ingrained in his historical memory that he did not need to make notes when he revisited the Norwich Carmelite library in $1527-8$, or that his knowledge of Gerard represents an oral tradition, perhaps learned abroad, the source of which he did not note down.

The failure to record the circumstances of his reading, or hearing about Gerard of Nazareth is disappointing because it renders a putative connection between Bale and the Centuriators speculative. A comparison of the list of hermits in the De conversatione servorum Dei from Bale's manuscript with those in the Duodecima centuria reveals certain disparities:

Matthias Flacius Illyricus, Duodecima centuria, $1603-10:^{18}$
A Jerusalem: Ralph, Alberic, Cosmas, John
B Mt Tabor: Walter, Rainald of Galilee
C Nazareth: Dominic, Bernard
D Black Mountain: Bartholomew, Henry
E Machanath: Bernard of Blois, Porphyry, William, Hugo, Walter, Hugo
F Jubin: Ursus, Valerius
G Carraria: John, Ralph, Sigerius
H Palmaria: Elias

John Bale, Cronica, ms Selden Supra 41, fo. I48v:

Helias abbas $(\mathrm{H})$

Galfridus abbas

Dominicus de Nazareth $(\mathrm{C})$

Bernardus heremita $(C)$

Cosmas ungarus (A)
Bernardus Blesensis (E)

Robertus Hierosolos. (E)

Bernardus patriarcha Hier.

Porphirus monachus (E)

Ursus eremita $(F)$

17 Fairfield, John Bale, $15^{8-9}$.

${ }^{18}$ Kedar, 'Gerard of Nazareth', 71-5, gives the full entry for each hermit, which will not be reproduced here. The groupings of hermits are as arranged in the Duodecima centuria and Bale's Cronica, but the capital letters are mine. 
ANDREW JOTISCHKY

Radulphus monachus (A)

Albericus monachus (A)

Bartholos. [sic] montane nigre (D)

Segerius abbas (G)

Nicholas monachus

Henricus monachus (D)

Rainaldus Jordanis (B)
Guilelmus monachus (E)

Hugo monachus (E)

Walterus monachus (E)

Valerius Burgundus (F)

Johannes solitarius (A) or (G)

Johannes alius monachus $(A)$ or $(G)$

Bale's list has twenty-three names to Matthias's twenty-two, but includes only one Ralph to Matthias's two, while Bale's Robertus Hierosolos., Galfridus and Nicholas have no counterpart in Matthias. Since Bale does not divide his names according to region or monastery as does Matthias, it is hard to tell which John and Ralph he meant to include. The groupings of hermits, however, do seem to be significant. ${ }^{19}$ Bale's right-hand column contains eight successive hermits associated by Gerard (through the Centuriators, at least) with the houses of Machanath and Jubin. ${ }^{20}$ As Gerard's entries for Bernard of Blois (which are scattered throughout three chapters of the Duodecima centuria but formed part of chs xvii, xviii, xix, xx of Gerard's work) make clear, the histories of the two houses were closely linked. ${ }^{21}$ Bernard and Robert founded the priory of Jubin, but a schism in the community forced them into exile in Jerusalem, where they obtained permission from the patriarch to enter Machanath. By grouping all the monks from these two houses together, Bale may be representing Gerard's original account of the Jubin/Machanath affair, which was lost by Matthias's reorganisation. If this is so, we may assume that the two Jubin monks, Ursus and Valerius, should in fact be taken with the Machanath monks, and that all these should be identified as those who took Bernard of Blois's side in the schism and left Jubin for Machanath. If such a reconstruction is valid, further identifications may be made for those monks not mentioned by Matthias. Patriarch Bernard (whose presence is something of a mystery) may have been assumed by Bale to have been a monk at Jubin and later Machanath.

Gerard included both members of communities and anchorites in his work, though he refers to them indiscriminately as monks. Bale's left-hand column appears to be made up largely of those of Gerard's hermits who lived a solitary life, with the apparently illogical additions of the abbots Elias of Palmaria, Galfridus and Segerius. All the others were genuine solitaries: Dominic and Bernard in Nazareth, Cosmas, Radulphus and Albericus in Jerusalem, Henry and Bartholomew on the Black Mountain and Rainaldus on Mt Quadragesima. Nicholas, unknown to Matthias, may also be surmised to have been a solitary, probably (to go with Henry) on the Black Mountain. Johannes solitarius, near the bottom of the right-

${ }^{18}$ I am grateful to Giles Constable for suggesting ways of studying the groups (in private correspondence).

20 Robertus Hiersolos. does not appear on his own in the Duodecima centuria, but must be the same 'Robertus de Ierosolymis' given by Gerard as a companion of Bernard of Blois: Duodecima centuria, 1605 .

21 Matthias, Duodecima centuria, 1605-6, 979, 1230; Kedar, 'Gerard of Nazareth', 72-3. 
hand column, refers to the John placed by Matthias at Jerusalem, who left his monastery to live in a deserted abbey on the Black Mountain but was forced by hunger to return to Jerusalem. ${ }^{22}$ Bale's other John must therefore be John of Carraria, who was presumably not listed with Segerius because much of his career was spent in solitude on the wooded slopes of Mt Tabor. ${ }^{23}$

Bale's cursory list, frustrating in its brevity, is followed by these notes on five hermits:

fo. $148 v$ :

Dominicus de Nazareth, religiosus vir, cuius eius [sic] vestitus, talaris tunica de candido vellere cum capucio, et altera brevior interius, cum caligulis.

Porphirius monachus, cum tunica cilicina, et cuculla sine manicis, colore candida, scil. vilis materia $[s i c]$.

'Bartholomeus in montana nigra religionis habitum sumpsit'.

fo. $148 \mathrm{r}$ :

Ursus heremita devotus maria vigine [sic] sepius orare consuerit, non modico fervore.

Bernardus monachus patriarcha hierosolymitanus, vir plurime virtutis et decorus.

Of Dominic, Gerard says that he was illiterate, but much admired for his austerity. He lived in the atrium of a church on a bare floor, and was always barefoot; he never laughed or spoke. Gerard himself offered to teach him elementary letters and how to read the Psalms, but he refused it as a waste of time. There is no mention of his habit. ${ }^{24}$ Porphyry, the successor of Bernard of Blois at the convent of Machanath on the Black Mountain, was perpetually barefoot and his feet unwashed. The vocabulary used by Gerard to describe his clothing is virtually identical to Bale's: 'Tunica usus est cilicina, et cucullo candido sine manticis'. ${ }^{25}$ Bale's note on Ursus's devotion to the Virgin Mary is extended in the Centuriators' extract from Gerard, who reported that Ursus had a habit of leaving his abbey (Jubin, also on the Black Mountain) and climbing to the top of the mountain whenever troubled, shouting for the Lord and the Blessed Virgin to guide him. ${ }^{26}$ Bartholomew, according to Gerard, put aside his wife and native land to go on pilgrimage to Jerusalem, where he became a Templar. He worked with another of Gerard's hermits, Alberic, in a lazar-house in Jerusalem before leaving for the Black Mountain, where he died. ${ }^{27}$

Bale's list adds three new names to the list of hermits already known from the Duodecima centuria: Galfridus abbas, Nicholas monachus and Bernard, patriarch of Jerusalem. Galfridus and Nicholas may have been genuine hermits known to Bale, but Bernard must surely be a mistake, since nobody by that name is known to have become patriarch of
${ }^{22}$ Matthias, Duodecima centuria, 1603.
${ }^{85}$ Ibid. 1606.
${ }^{26}$ Ibid. 1607 .
${ }^{23}$ Ibid. I607-8. ${ }^{24}$ Ibid. 1604.
27 Ibid. 1605 . 
Jerusalem. It is possible that Bale had in mind Bernard de Valence, patriarch of Antioch from I I 00 to 1135 , though it is hard to see what connection Bernard might have had to the eremitical life.$^{28}$ Bale may have known of a Carmelite tradition linking Bernard to the Black Mountain or to an eremitical foundation, but if so his source has yet to be discovered. It is hard to believe that Gerard, a contemporary of Bernard's, could have made such a mistake.

The similarity between the lists in the Cronica and the Duodecima centuria extends to the figure of Gerard of Nazareth himself. As Kedar has pointed out, Gerard was an important suffragan bishop of Aimery, patriarch of Antioch, and active in ecclesiastical affairs both in Antioch and Jerusalem. He was present at the council deposing Ralph de Domfront, patriarch of Antioch, in 1140 , and later at the submission of Reynaud de Chatillon to the Emperor Manuel Comnenus at Easter II $59 .{ }^{29}$ Gerard's career is mentioned cursorily in the Duodecima centuria, but in remarkably similar terms to the words used by Bale in his introduction to the list of Gerard's hermits :

\section{Matthias Flacius Illyricus, Duodecima centuria, I 379-80:}

Gerardus a Nazareth, patria Galileus, ordinis S. Benedicti monachus primum prope Nazareth, deinde apud Antiochiam Carmelitanae sectae eremitae, claruit anno I I 40. ut ipse testatur cap 2. de conversatione servorum Dei. Tandem Laodicensis fit episcopus. In sacris literis eruditum fuit, philosophus et rhetor insignis, Graece et Latine doctus. scripsit De conversatione servorum Dei lib. I, Ad ancillas Dei apud Bethaniam lib. I, Vitam abbatis Eliae lib. 1, De una Magdalena contra Graecos lib. I, Contra Salam presbyterum lib. I, atque alia nonulla.

John Bale, Cronica, ms Selden Supra 4I, fo. I48v:

Gerardus a Nazareth, Galileus genere (quem Benedictum esse ferunt) de monasterio montane nigre prope Antiocham, episcopus Laodicensis, hermita sanctissimus, rhetor, et theologus. Scripsit ad Guillelmum presbiterum, de conversatione servorum Dei, vitam abbatis Helie, de Maria Magdalena, ad ancillas Dei in Bethania, contra Salam presbiterum, et alia, floruit $1140{ }^{30}$

${ }^{28}$ Willelmi Tyrensis Archiepiscopi Chronicon xiv. 10, ed. R. B. C. Huygens, Corpus Christianum Continuatio Medievalis IxiiiA, 641 .

${ }^{29}$ Kedar, 'Gerard of Nazareth', 62-3; R. Röhricht, Regesta Regni Hierosolymitani Iog7-I29I, Innsbruck I893-1904, nos 338, 359, 366; Willelmi Tyrensis Archiepiscopi Chronicon xv. 16 , and xviii. 23 , pp. 696,845 .

${ }^{30}$ Josiah Simler's edition of C. Gesner's Bibliotheca universalis, Zürich 1574, 237, has a similar entry for Gerard: 'Gerardus a Nazareth, patria Galilaeus, apud Nazareth primum, deinde in Montana Nigra prope Antiocham eremita, episcopus tandem Laodicensis, Graece et Latine doctus, scripsit ad Guilhelmum presbyterum, De conversatione servorum Dei, lib I. Vitam abbatis Heliae, lib 1. De una Magdalena contra Graecos lib I. Ad ancillas Dei in Bethania lib I. Contra Salam templarium lib I. Atque alia. Claruit anno Domini $ı$ I $0^{\prime}$ '. Kedar, 'Gerard of Nazareth', 6o, suggests that Simler may have had access to another manuscript of Gerard, or may have read the Duodecima centuria and chosen not to copy the Centuriators' mistake in calling him a Carmelite. It is unlikely that his knowledge of Gerard came only from Bale, since he knew that 'De una Magdalena' was written 'contra Graecos', while Bale apparently did not know. 
The similarities between Bale's and Matthias's entries for Gerard, taken together with the lists of hermits, suggest a common source. As Kedar has already shown, the only other passage from Gerard's work known to us is that quoted by the Carmelite historians of the fourteenth century. ${ }^{31}$ Bale was certainly familiar with Ribot's work: the copy of Ribot's De institutione et peculiaribus gestis religioserum Carmelitarum in Lambeth Palace Library, ms 192 , has notes in Bale's hand and may have been owned by him. ${ }^{32}$ Another of Bale's manuscript notebooks, BL, ms Cotton Titus D x, dating from between 1548 and 1560 , contains extracts from the $D e$ institutione (fos I I v-26r). This manuscript, as scholars of Bale have known for some time, makes explicit the connection between Bale and the Centuriators. Like Selden Supra $4 \mathrm{I}$, the manuscript is a compilation of catalogues and miscellanea dealing with Carmelite history and apologetics, some, like the extracts from Ribot, incomplete. Towards the end of the manuscript are examples of Bale's correspondence, including a letter to Bale from Matthias Flacius, dated I 554. The letter asks for the ex-Carmelite's help in the Centuriator's project of compiling a Protestant history of the Church. ${ }^{33}$ Bale had first fled to Germany in 1540 , expecting a Catholic reaction after Cromwell's downfall, and there published anti-Catholic polemical works. He was consecrated bishop of Ossory in $\mathrm{I}_{552}$ to bring the Reformation to Ireland, but met with intransigence, and fled first to Holland and then Basle in $1553 .{ }^{34}$ Matthias's letter was written when Bale was already in Basle - where the Centuriators' Ecclesiasticae historiae was to be published eight years later.

Because of the nature of the Centuriators' compilation, it is impossible to know whether they had more information at their disposal than did Bale. Bale, too, was highly selective. The paucity of his notes is frustrating for the historian, but fits in with the general tenor of the Cronica. There are lacunae in some of the entries, particularly in the period from the seventh century to the eleventh, and several pages in the manuscript have been left blank, or the red circles have been drawn but not filled in, suggesting that this may have been the author's rough copy. ${ }^{35}$ Bale may have had more information at his disposal which is simply not included in Selden Supra 41. Without an original manuscript against which to compare the lists in the Cronica and the Duodecima centuria, it is impossible to know how far the Centuriators might have relied for their information on Bale. That they did so in other parts of the Duodecima centuria is indisputable. Another hermit, the problematic 'Cyrillus Carmelitus', appears in the same

31 Kedar, 'Gerard of Nazareth', 56-7.

32 Lambeth Palace Library, MS 192, fo. 44v, contains a list of Carmelite bishops in Bale's hand. M. R. James, A descriptive calalogue of the manuscripts in the Lambeth Palace Library, Cambridge I930, 300, suggests that Bale owned the manuscript.

${ }^{33}$ BL, ms Cotton Titus D x, fo. $18 \mathrm{Iv}$. The correspondence between Bale and the Centuriators is printed in H. McCusker, John Bale: dramatist and antiquary, Bryn Mawr 1942, 67-70. $\quad{ }^{34}$ A full account of Bale's movements can be found ibid.

${ }_{95}$ The red circles have been left empty on fos I I Ov-11r, and the blank pages are fos $12 \mathrm{IV}, 122 \mathrm{r}, 124 \mathrm{r}, 125 \mathrm{v}, 13^{8 \mathrm{r}}-40 \mathrm{~V}, 14 \mathrm{Ir}, 142 \mathrm{v}, 144 \mathrm{v}-\mathrm{r}$ and $146 \mathrm{r}$. 
chapter as Gerard's hermits. Cyril was of great importance in Carmelite historiography: he is one of the contemporary 'sources' on which Ribot claimed to base his account of the Carmelites in the thirteenth century. ${ }^{36}$ The Centuriator's entry for Cyril quotes several lines of a poem on Cyril by the Carmelite author Baptista Mantuanus $(f$. 1513-16), for which Bale's Scriptorum Maioris Britanniae...catalogus (1544-7), was acknowledged as the direct source. ${ }^{37}$ Another important figure in Carmelite historiography, Brocardus, revered as the second prior-general of the order, appears in the Duodecima centuria as the original author of the Rule for which Albert, as ultimate ecclesiastical superior of the province in which the Carmelite foundation was located, took the credit; again, Bale is quoted as the source. ${ }^{38} \mathrm{~A}$ more important contribution from Bale, however, was a general entry on the Carmelite Order, in which the Centuriators seem to accept Carmelite traditions establishing the continuity of Carmelite existence from the 'Byzantine period' into the twelfth century. ${ }^{39}$ The Centuriators wrote to Bale in I 553 and I 554 , some years after the Catalogus had made him famous in continental Protestant circles. There is, thus, no way of linking the Centuriators' use of Bale's Carmelite material directly to their correspondence of 1553 and $1554 .^{40}$

The Centuriators either had at their disposal a different copy of Gerard from that known by Bale, or at any rate enough information from unknown sources to reject from the canon of Gerard's hermits Nicholas, Galfridus and Patriarch Bernard, adding instead another Ralph, Hugo and Walter. The case of Bernard may be instructive here. It seems that he was added by Bale - or an earlier Carmelite tradition - simply to bolster the prestige of the order. If the Centuriators suspected this, it would explain his omission from their text. Indeed, as Kedar has pointed out, ${ }^{41}$ more than a third of the chapters of the De conversatione were not used at all by the Centuriators, perhaps because they suspected Carmelite additions to Gerard's original. It cannot be said with any degree of certainty that Gerard's De conversatione was made known to the Centuriators by Bale alone, as a consequence of the correspondence of I 553-4: Bale and the Centuriators may have relied on different versions of Gerard. Because of the fragmentary nature of their presentation of

${ }^{36}$ Cyril appeared in Bale's Cronica in a red circle as the third prior-general of the Carmelite Order: Bodl. Lib., ms Selden Supra $4^{1}$, fo. I5or.

${ }^{37}$ Matthias, Duodecima centuria, i6 ro: 'de quo Baleus hosce scribit versiculos ex Mantuano lib 5 Fastorum'.

${ }^{38}$ Ibid. I 370 . The information is ascribed to Bale's Catalogus, the appendix to ch. xli of Centuria 133 .

${ }^{39}$ Matthias, Duodecima centuria, 944-5. The Centuriators' acceptance of Carmelite chronology is indicated by the entry for Gerard himself, which includes the phrase 'apud Antiochiam Carmelitanae sectae eremita', 1379.

40 Bale explained in a letter to Archbishop Parker in 1560 that the bulk of his considerable library had been left behind in Ireland and impounded by his enemies; he was thus hardly in a position to send manuscripts or books to the Centuriators in 1554 , after his flight. For the Parker-Bale correspondence see McCusker, John Bale, 67-8.

${ }^{41}$ In private correspondence with the author. 
Gerard's material, however, the suspicion must remain that the Centuriators' knowledge of the De conversatione-and thus, our own knowledge of the text - derived ultimately from the Carmelite historical tradition. What does seem clear is that the version of the De conversatione known by Bale, almost certainly from Carmelite sources, included additional material linking Gerard and his hermits to the alleged twelfthcentury development of the Carmelite Order. However much of such excesses the Centuriators were able to prune, they were reliant enough on Bale to believe, from a reading of his Catalogus, that Gerard himself had been a Carmelite.

Philip Ribot cites Gerard of Nazareth's prologue to the De conversatione in the context of a discussion of the virtues of eremitical life:

Gerardus episcopus Laodicensis in libro de conuersatione uirorum Dei in Terra Sancta morantium, ad Guilelmum presbyterum: Aliud est genus religiosorum qui sigillatim habitant a saeculi rebus alieni, quod laudabile semper fuit. Hi sunt qui ad exemplum Eliae silentium solitudinis praeferunt tumultibus civitatis. Amant enim secretam contemplationem Deitatis. Unde David a saeculi molestiis in solitudinem fugiens se elongabat. In terra, inquit, deserta, invia et inequosa [sic]: sic in sancto [sic] apparui tibi, ut viderem virtutem tuam, et gloriam tuam. Hanc quippe gloriam Moyses in deserto, hanc tandem Elias in solitudine quaesierunt videre. Hinc et Salvator in monte, seorsum a turbis, inter Moysem et Eliam gloriosus effulsit. ${ }^{42}$

Ribot thus uses Gerard to expound the Carmelite argument that Elijah was the true exemplar for the eremitical life. He also makes use of other figures active in the twelfth-century Church in Outremer in the same way. Patriarch Aimery of Antioch ( I 40-93) plays an important role in Ribot's $D e$ institutione in the development of a regulated community of hermits on Mt Carmel. Learning that recent Frankish recruits to Mt Carmel were not observing traditional Carmelite practice, he had their original Rule, which Ribot attributes to John, a fifth-century bishop of Jerusalem, translated from Greek into Latin:

Intelligens autem quosdam eorum qui ex Occidente supervenerunt, spretis seniorum monitis, non recte ambulare ad [sic] veritatem religiosae vitae eremitae, in praedicto Joannis libro descriptae, et perpendens hoc ideo maxime contigere, quia Graecas litteras ignorantes, nesciebant codicem illum legere, fecit librum illum de Graeco in Latinum transferri. ${ }^{43}$

There is no evidence from Aimery's long patriarchate of any connection with Mt Carmel. The idea of his intervention in the affairs of an eremitical foundation on Mt Carmel must have been inspired by a passage in

42 Philip Ribot, De institutione et peculiaribus gestis religiosorum Carmelitarum iii. 8, from the edition of Daniel a Virgine Maria, Speculum Carmelitarum, i. 36. Kedar, 'Gerard of Nazareth', 56, edits this extract from three manuscripts (Rome, Archivio Generale dei Carmelitani, Collegio Sant' Alberto ms II C.O. II 35; Trier, Stadtbibliothek ms I55(80)/1237; and Munich, Staatsbibliothek ms Clm 471).

${ }_{43}$ Ribot, De institutione viii. 2, p. 75. 
Gerard's De conversatione, where Aimery is described as regulating against solitary anchorites on the Black Mountain outside Antioch: 'Is [Aimery] sedulus vitae monasticae promotor fuit, ut Gerardus a Nazareth testatur. Legem tulit, ne quis in monte Nigro sine maiore inspectore solitarius' ${ }^{44}$ The point of Ribot's 'poaching' of Aimery is to demonstrate the alleged continuity of Carmelite settlement from the 'Byzantine' to the 'Frankish' period, which is untenable from contemporary sources. ${ }^{45}$ Despite his interest in hermits, however, Aimery was a singularly unlikely figure to choose for the role assigned to him. His troubled relations with the Orthodox Church in his province make it improbable that he should have had a Greek Rule for hermits translated into Latin, especially when there were plenty of Latin ones available. Partly as a result of the submission of Reynaud, prince of Antioch, to Manuel Comnenus in I I59, Aimery was forced into exile and a Greek patriarch installed in his place in I 65 . On his return to office, he cultivated the friendship of the anti-Greek Jacobite Patriarch Michael, whom he eventually invited to attend the Third Lateran Council in Rome. ${ }^{46}$ His correspondence with the Pisan theologian at the court of Manuel Comnenus, Hugo Etherianus, shows his interest in using theology in polemical debate; Hugo sent him a copy of his book De haeresibus quos Graeci in Latinos devolvunt, and Aimery asked for others, including an account of the Council of Nicaea and a history of Constantinople. ${ }^{47}$ This exchange of letters occurred in 1176 , after Aimery's restoration to office in Antioch. ${ }^{48} \mathrm{His}$ choice of books is revealing in the light of Hugo's understanding of his own work. The preface to the De haeresibus makes it clear that Hugo was writing a defence against the attacks of Greek theologians. ${ }^{49}$ A Latin bishop who had been ousted from

44 Matthias, Duodecima centuria, I 373. Aimery's treatment of the hermits of the Black Mountain is further complicated by a passage in Otto of Freising's Chronicon. In I 143 Hugh, bishop of Jabala, while organising the defence of the city of Antioch had, according to Otto, depopulated the countryside around the city of its hermits. 'Ille [Hugh] autem, eo quod a principe delusus esset, civitati quidem pepercit, sed totam ferro flammaque depascens provinciam heremitas quoque, quorum grandis ibi copia est, de cellulis suis eductos, non kalo, id est boni, Iohannis [Comnenus] officium agens, crudelissime tractavit': Chronicon, sive de duabus civitatibus vii, 28, ed. A. Schmidt and W. Lammers, Darmstadt I96I, 548. It is possible that Aimery's legislation against solitary anchoresis was also inspired by concern for the hermits' safety.

45 For the same reason Ribot quotes from Gerard not, as did Bale, the names of hermits themselves, but rather a more general definition of the practices of hermits. The passage, cited alongside similar ones from John Cassian and Isidore of Seville, implies that the hermits who followed the example of Elijah in the twelfth century were following early Christian practice.

${ }^{46}$ Michael the Syrian, Chronique, ed. and trans. J.-B. Chabot, new edn Brussels ig63, 377-8. Aimery also secured the union of the Maronite Church with Rome in 1182.

${ }^{47}$ PL ccii. 229-32. For Hugo's career see A. Dondaine, 'Hugues Éthérien et Léon Toscan', Archives d'histoire docirinale el littéraire du Moyen Age xxvii (I952), 67-134.

48 The carrier of the letters was Reynaud de Chatillon, who had just been released from prison in Aleppo: B. Hamilton 'Manuel I Comnenus and Baldwin IV', in J. Chysostomides (ed.) Kathegetria, Camberley 1988,360 . I am grateful to Professor Hamilton for pointing this out to me.

${ }^{49}$ PL ccii. $232-3$. 
office as a result of disputes between the prince of Antioch and his Byzantine overlord, and who was on friendly terms with a Latin theologian writing polemics against Greek views of the Trinity was hardly likely to translate a Greek monastic rule for the use of Frankish hermits: a far more likely interpretation of his legislation for hermits was that he did not want solitary Franks falling under the influence of Orthodox monks on the Black Mountain.

Aimery was established by Ribot as one of the most important figures in the regulation of the Carmelites. Embellishing Gerard's evidence about Aimery's action against unsupervised hermits, Ribot argued that Aimery had actually established a community of hermits in caves on the Black Mountain. ${ }^{50}$ The Black Mountain, just outside Antioch, was a more likely field of activity for Aimery than Mt Carmel, which lay outside his ecclesiastical jurisdiction. It was well known as a centre for monastic and eremitic life by the twelfth century among both Latins and Orthodox. Ribot extended the connections between the Black Mountain and the Carmelites by introducing the figure of Eusebius, 'prior of the Black Mountain'. Eusebius features in the De institutione only as the recipient of the 'letter of Cyril of Constantinople'. This 'letter' - which has become a vital source for subsequent Carmelite historiography $y^{51}$ - was, with the 'Rule of John of Jerusalem' and the 'Chronicle of William of Sandwich', one of the sources on which Ribot claimed his work was based. None of these works, however, can be found before the De institutione, and modern scholars view them as literary devices invented by Ribot to give greater authenticity to his work. ${ }^{52}$ Eusebius, therefore, looks very like a creation of Ribot's, designed both to enhance the connection between the Black Mountain and Mt Carmel and, once again, to emphasise the continuity of the Carmelite profession. By the sixteenth century, however, he was firmly established in Carmelite history: Bale lists him in the Cronica as 'Eusebius heremita montis Carmeli, Cirilli discipulus' ${ }^{53}$

Ribot also connected the two eremitical sites directly through the person of Aimery. In a later chapter he went on to say that the way of life established for the hermits by Aimery on the Black Mountain was actually that of the Carmelites:

Nonullos quoque eorum duxit Aymericus patriarcha Antiochenus in solitudinem montis Neroi, qui alio nomine montana nigra apellatur, ubi in antris absconsam vitam Domino servabant. Qui omnes quamvis essent locis sejuncti, eandem tamen vitam solitariam servare satagebant, quam servabant eremitae montis Carmeli. ${ }^{54}$

This found its way, probably through a confusion of the two sites by Bale, to the Duodecima centuria:

${ }^{50}$ Ribot, De institutione ix. I, p. 96.

${ }^{51}$ See especially G. Wessels, 'Epistola S. Cyrilli Generalis et historia antiqua Ordinis nostrae', Analecta Ordinis Carmelitana iii (1914), 267-86.

${ }^{82}$ On William of Sandwich, for example, see Egan, 'An essay', 80-2.

${ }^{53}$ Bodl. Lib., ms Selden Supra 41, fo. I5 Iv. ${ }^{64}$ Ribot, De institutione ix. I, p. 96. 
Almericus Antiochenus patriarcha, sedis Romanae in illas partas legatus, anno I 12 I eremitas in Carmelo dispersos collegit in unum, et redegit in ordinem, qui a loco dicti sunt Carmelitae... Baleus Cent 2 ca 66 in appendice Scriptorum Britanniae..$^{55}$

The Centuriators were thus, wittingly or not, colluding in Carmelite attempts to create a spurious past for their order. While Ribot retained the Black Mountain to emphasise the plausibility of his account of the Carmelite Order in the twelfth century, Bale simply 'annexed' Aimery to his Carmelite genealogy. But he went further still by including in his genealogy Peter the Hermit, Gerard the 'founder of the Hospital of St John' and 'Sibylla', daughter of King Fulk and Queen Melisende and abbess of Bethany. ${ }^{56}$ Gerard's De conversatione could be used to supply others. Of the twenty-six hermits known from Matthias and Bale, two, Henry and Bartholomew, settled either alone or in unspecified communities on the Black Mountain, and eight others-Bernard of Blois, Porphyry, William, Walter, the two Hugos, Ursus and Valerius - were monks in the new foundations of Machanath or Jubin on the Black Mountain. Ribot does not make use of Gerard's hermits to bolster his account of the Carmelite foundation, but he does list the Black Mountain as one of the sites to which the Carmelites expanded in the thirteenth century, along with Mt Quarantenus, another celebrated hermits' site, Tyre, Sidon, Tripoli, 'Mt Lebanon', Antioch, Jerusalem and the Galilee. ${ }^{57}$ Bale's inclusion of Gerard's hermits shows that he considered them to be inside a wider Carmelite sphere, even if he was unsure of their exact relationship to Mt Carmel.

This poaching of any individuals who had suitable connections to the monastic or eremitical life appears clumsy and transparent in the case of people whose careers are well documented, such as Peter the Hermit, Patriarch Aimery or Gerard, putative founder of the Hospital of St John in Jerusalem. A brief examination of the established facts of the eremitical foundation on Mt Carmel, however, will show that the connections made by Ribot and later Carmelite apologists between different monastic settlements, and specifically between the hermits of Gerard of Nazareth and the Carmelites are not, perhaps, so far-fetched.

The keystone of the Carmelite historians' account of the 'Frankish period' of the order is the figure of Berthold. Ribot, the first to mention him, says that he was established in the office of prior-general of the

${ }^{55}$ Matthias, Duodecima centuria, 1374; Bale, Scriptorum illustrium maioris Britanniae ... catalogus, Basel I559, I82. Bale's Cronica mentions Aimery's regulation of the Carmelites under the entry for Berthold, Bodl. Lib., ms Selden Supra 41, fo. I48r. The Centuriators, by including Bale's evidence as well as Gerard's, preserved two different, but not mutually exclusive, traditions about Aimery.

${ }^{56}$ Bodl. Lib., Ms Selden Supra 41, fo. 147v, 148r. Gerard of Nazareth had written a sermon 'ad ancillas Dei in Bethania'. The real abbess of Bethany was named Yveta. Sibylla, who became countess of Flanders, was the daughter of Fulk, but not of Melisende.

${ }^{57}$ Ribot, De institutione ix. 2, p. 97. The list of Carmelite foundations in the Latin East given by Bale also includes Acre, Bethel and 'Calgala': BL, ms Cotton Titus D x, fo. $125 \mathrm{v}$. 
Carmelite Order by Aimery of Antioch in I $121{ }^{58} \mathrm{He}$ ruled for forty-five years, was called by Bale 'sacre pagine doctor' and, according to him, performed I 5 miracles, including the healing of two paralytics. ${ }^{59}$ The figure of Berthold, despite later embellishments, may have been based on a real hermit. Twelfth-century pilgrims knew Mt Carmel as the place sanctified by Elijah's triumph over the priests of Baal, but the first evidence of a settlement there occurs in the report of the Jewish pilgrim Benjamin of Tudela in the late 1 i 60 s that Christians were living by the cave of Elijah, where they had built a church dedicated to the prophet. ${ }^{60}$ The cave - venerated still today by Jews, Christians and Muslims - lies at the foot of the north-western slope of $\mathrm{Mt}$ Carmel. Directly above, on the summit, the present Stella Maris Carmelite monastery occupies the site of the medieval Greek monastery of St Margaret. ${ }^{61}$ In the sixth century there had been a monastery on Mt Carmel dedicated to Elisha; ${ }^{\mathbf{2}}$ the church reported by Benjamin may have been associated with a monastery, by then abandoned, in which hermits, either Orthodox or Frankish, were living. Further evidence for the re-use of this site comes from the account of the pilgrim John Phocas, a Cypriot monk who visited the Holy Land in 1 1 85. Describing the ruins of St Elisha, John says that not many years before his pilgrimage a white-haired monk from Calabria had been called to the site in a vision by Elijah, had built a tower from the ruins of the abbey and settled there with about ten brothers. ${ }^{63}$ The fact that he figures at all in Phocas's account, and his place of origin, suggests that he was Greek Orthodox.

The anonymous Calabrian became Ribot's model for Berthold, the first 'crusader' Carmelite. ${ }^{64}$ By smoothing over the complex topography of $\mathrm{Mt}$ Carmel, Ribot was able to claim any monastic or eremitical foundation on

${ }^{58}$ Ribot, De institutione viii. 2, p. 75. The dating gives Ribot away; Aimery did not become patriarch until I 140 .

59 Bodl. Lib., ms Selden Supra 4I, fo. 147r. Bale adds to the legend by making Berthold a crusader who took part in the capture of Jerusalem in 1099 and afterwards became a follower of Peter the Hermit.

${ }^{60}$ Benjamin of Tudela, Itinerary, ed. M. N. Adler, London 1907, I9. For the Jewish cemetery near the cave of Elijah, see J. Prawer, The history of the Jews in the Latin Kingdom of Jerusalem, Oxford I 988,83 . Earlier twelfth-century pilgrims who mention Elijah include the Russian abbot Daniel ( $1 \mathrm{I}_{5-6}$ ), The pilgrimage of the Russian Abbot Daniel (Palestine Pilgrims Text Society iv, I 895), 55, and Rorgo Fretellus (I I37), Rorgo Fretellus de Nazareth et sa description de la terre sainte, ed. P. C. Boeren, Amsterdam 1980, I 9.

${ }^{61}$ Friedman, 'The medieval Abbey of St Margaret of Mt Carmel', Ephemerides Carmeliticae xxii (197 I), 295-348.

${ }^{62}$ Antonini Placentini itinerarium iii, ed. P. Geyer, CC cluxv. 130 : 'A Ptolemaida per mare incontra in civitatem Sucemina Iudeorum est miliario semis per directo, littore maris milia sex. Castra Samaritanorum a Sucemina miliario subtus monte Carmelo. Super ista castra miliario semis monasterium sancti Helisaei, ubi ei occurrit mulier, cuius filium suscitavit'.

${ }^{63}$ John Phocas, Descriptio Terrae Sanctae, PG cxxxiii. $96 \mathrm{I}-2$.

64 Ribot, De institutione viii. 2, p. 75. The Calabrian soon became indistinguishable from Berthold, the first prior-general, and even in modern Carmelite scholarship Phocas's account is taken as evidence for the settlement of Mt Carmel in the twelfth century: Monumenta historica Carmelitana, ed. B. Zimmermann, Lirinae I907, i. 269. 
the mountain as 'Carmelite'. An examination of the sixth-century description of the monastery of St Elisha, however, suggests that the Calabrian's settlement cannot have been on the promontory of the mountain, by the cave of Elijah, but instead farther to the south. Elias Friedman locates St Elisha in Nahal siah, the site of the eremitical settlement described by Jacques de Vitry, and by numerous thirteenthcentury pilgrims, and confirmed by papal bull in $1226 .^{65}$ If Friedman is correct, the settlement described by Benjamin, which he locates precisely at the cave of Elijah, and that described by Phocas, were not the same. The ruins of St Elisha were some seven kilometres to the south of the cave, by the spring of Elijah. This location is confirmed in the prologue to St Albert's Rule, written between 1205 and I 2 I4 and addressed to ' $B$. et caeteris eremitis qui sub eius obedientia iuxta fontem in Monte Carmeli morantur' ${ }^{66}$

Albert's Rule is the earliest independent evidence for the existence of the hermits who were to become the Carmelite Order. Somewhat disingenuously, Ribot merged two different eremitical settlements into one to prove that the Carmelite Order was older than St Albert's Rule. From there it was easy enough to extend the net to include other figures who can have had no relation to the hermits addressed by St Albert.

Albert's Rule is succinct and brief, but it includes important details about the settlement of $\mathrm{I205}^{-14}$ in Nahal siah. Significantly, Albert acknowledges that the settlement is already in existence; his Rule is supplied at the request of the hermits themselves. ${ }^{67}$ Albert organised the hermits according to a traditional plan that owes much to eremitical communities in western Europe from the ro5os onwards. Peter Damian, Stephen of Obazine or Bruno the Carthusian would have recognised elements of their own ideas in the Carmelite hermitage. There were twelve hermits, one of whom was elected prior by the others. They lived in individual cells grouped around an oratory, ate in a common refectory and kept the canonical hours according to the usage of the Church of the Holy Sepulchre. They owned nothing, but held pack-animals in common; they met in chapter every week; their work was divided between physical labour and meditation. They were to live in the place assigned them by the prior, and keep to it unless instructed otherwise. They were not permitted to leave the hermitage without the prior's permission. ${ }^{68}$

The hermitage in Nahal siah cannot be dated, for lack of evidence, earlier than the Rule of St Albert. Its way of life, however, recalls similar hermitages or proto-monastic foundations described by Gerard of Nazareth two generations or more earlier, particularly those on the Black Mountain. The example of Bernard of Blois provides a parallel. At some point before I I 23 Bernard and a few companions, amongst them Robert of Jerusalem, founded a house at Jubin, on the Black Mountain. Gerard

${ }^{65}$ Friedman, 'Abbey of St Margaret', 314.

${ }^{B 6}$ The Rule of St Albert, ed. and trans. Bede Edwards, Aylesford 1973, 78.

67 Ibid.

68 Ibid. 80-8. 
mentions a rule devised by the community, but of its content we know only the prohibition of all personal wealth and all donations over the value of three bezants. ${ }^{69}$ Whether this was one of a number of strictures in a new rule, or merely a strict interpretation of part of the Benedictine Rule, is not clear. The sense of the passage in the De conversatione is that Bernard left deliberately to found a new house rather than join an existing one, implying that he had in mind a community not yet bound to adherence to a rule. This is not to suggest that Bernard disapproved of monastic rules, but rather that, like many monks in western Europe, he saw a fresh start as the surest way of effecting reform. The same must have been true of the hermits of Nahal siah ; by the first decade of the thirteenth century, indeed, there was a much greater choice of monasteries for the prospective monk in the Latin East than there had been for Bernard, including the Cistercian abbeys founded after 1157 . Another example of the same type of foundation comes from Gerard's life of Elias of Narbonne, who joined a 'monasterium eremitarum' while on pilgrimage in the Holy Land, became a priest and later founded his own eremitical community in a cave near Jerusalem (probably in the 'vicus eremitarum" in the Kidron Valley) before being persuaded to join the abbey of St Mary de Josaphat, and subsequently becoming abbot of a house in Galilee that had begun as an eremitical foundation. ${ }^{70}$ Bernard's foundation at Jubin split apart on the principle of absolute poverty. The prior (not Bernard himself) relaxed so far as to accept gifts of money, food and wine, incurring the wrath of Bernard and a few others and causing a schism in the community. Bernard left Jubin in anger and returned to Jerusalem, but eventually received permission to enter the cloister at Machanath, another new foundation on the Black Mountain, which encouraged a stricter adherence to the Benedictine Rule. ${ }^{71}$ Later, under circumstances not mentioned in the De conversatione, Bernard returned to Jubin, which had become severely depleted as a result of the schism.

This episode, reminiscent of the schism at Molesme from which Cîteaux was eventually born, serves as a reminder of the uncertainties of monastic foundations. Not all were successful, and most of those that were not have left little trace. This is particularly the case in Latin Syria, where the countryside was often hostile or at least alien, and the danger of enemy incursions constant. After the battle of Hattin and the fall of the kingdom of Jerusalem in I 87 many monasteries ceased to exist, particularly daughter-houses and those without estates elsewhere. Later Carmelite

${ }^{60}$ Matthias, Duodecima centuria, 1605.

${ }^{70}$ Ibid. I603. For the abbey of Palmaria, see Kedar, 'Palmarée, abbaye clunisienne du XIIe siècle en Galilée', Revue Bénédictine xciii ( 1983 ), 260-9.

${ }^{21}$ Matthias, Duodecima centuria, I 230. Other monks of Machanath mentioned by Gerard were William and Hugo, both Frankish knights, Porphyry, Walter and another Hugo. The passages in the De conversatione dealing with Bernard are scattered across three chapters of the Duodecima centuria; the part describing the schism is hostile in tone and quite unlike the rest of Gerard's work, and may therefore be the work of another author. 
historians saw 1187 as a watershed in the history of their order. Bale's Anglorum Heliades cites a passage from the treatise De adventu Carmelitarum ad Angliam, attributed to an English Carmelite writing in about i 360 , Claudius Conversus (or William of Coventry), to the effect that, at the time of Saladin's conquest, many Carmelites were scattered throughout the Holy Land on preaching missions, as was customary before the adoption of St Albert's Rule. These fled to Cyprus and were restored to Mt Carmel by Richard I after the capture of Acre in I $190 .{ }^{72}$ Like Ribot, Walter was trying to confirm the existence of the order before St Albert's Rule. Doubtless many hermits and monks did flee the I 87 invasion (as the Carmelites would flee Mt Carmel temporarily in 1238 ) and return with the peace established by the Third Crusade, but to call them all Carmelites is anachronistic. Amongst the furtive hermits returning to Nahal siah may have been some who had lived alone elsewhere, perhaps in parts of the Galilee. One such earlier example from the De conversatione, John, had lived in the dense woods of Mt Tabor since rog8, and saw so little of human society that he did not know whether Antioch was still part of the Crusader States. ${ }^{73}$ Such hermits may have decided that a 'monasterium eremitarum' would give them greater safety after the fall of the kingdom of Jerusalem. There may have been amongst them, hermits from the Black Mountain, which was threatened by Saladin's invasion of the principality of Antioch in I I88. Given the frailty of eremitical foundations, moreover, it is quite possible that Frankish communities had settled on Mt Carmel before Albert's Rule, and that the hermits of Nahal siah were using a pre-existing site. Mt Carmel covers some twelve-and-a-half miles from north to south, and at least five different foundations are known from the sixth century onward: the Orthodox convents of St Elisha and St Margaret, the Calabrian eremitical settlement of the I I 7 os by the cave of Elijah, the Frankish hermits of Nahal siah and another Orthodox monastery, St John of Tyre, still farther to the south (in the wadi al-'ain). Pilgrimage accounts from the thirteenth century make the relationships and distances between these foundations clearer, ${ }^{74}$ but before $c$. 1230 it is impossible to tell what kind of overlap

72 BL, ms Harley 3838 , fo. 9v. In the summary edition of his Catalogus, Basel ${ }_{1559}, 461$, Bale attributed the treatise De adventu Carmelitarum ad Angliam, which he had copied into his own notebook, Bodl. Lib., ms Bodley 73, between 1520 and 1527 , to the Carmelite William of Coventry, also known as Claudius Conversus. Here he has William flourishing c. ${ }_{1360}$, but in the Cronica, Selden Supra 41 , fo. $167 \mathrm{r}$, he had specified the 1340 . In a later notebook, BL, ms Cotton Titus D x, fo. I27r, he attributed the work to a more recent Carmelite author, Richard of Ely (d. 1486). Zimmermann opted for Richard of Ely as the author: Monumenta, i. 364 . Another Carmelite author, Robert Bale, thought that Cyril of Constantinople fled to Mt Carmel as a result of Saladin's conquest in 1187 : Bodl. Lib., Ms Selden Supra 72, fo. 9 r.

${ }^{73}$ Matthias, Duodecima centuria, 1607.

${ }^{74}$ In particular three anonymous French accounts, 'Les chemins et les pélerinages de la Terre Sainte', 'Les sains pélerinages que l'en doit requerre en la Terre Sainte' and 'Les pelérinages por aler en Iherusalem', which are collected in Itinéraires à Jérusalem et descriptions de la Terre-Sainte rédigés en franfais aux XIe, XIIe et XIIIe siècles, ed. H. Michelant and G. Raynaud, Geneva I 882 . 
there might have been between eremitical and more permanent settlements. Eremitical settlements of Orthodox monks one might expect to have been absorbed by St Margaret's, just as the Latin hermits gathered under the unifying Rule of St Albert. Even in the thirteenth century, however, one cannot be sure that all hermits on Mt Carmel were living under a Rule.

If Ribot did not explicitly claim Gerard of Nazareth's hermits as examples of Carmelites before St Albert's Rule, the intent in his quotation from Gerard's De conversatione cannot be disputed. Gerard seems not to have written about Mt Carmel (at any rate, if he did, the relevant passages have been lost), but Ribot assumed that a hermit following the example of Elijah must have lived on the site of Elijah's most celebrated acts. Ribot's contemporaries Bernard Ollerius and John of Hildesheim, who quote exactly the same passage of the De conversatione, suggest the same. Ollerius takes Gerard's words to refer to hermits living on Mt Carmel before the Rule: 'Quod autem oporteat haec verba intelligi de praedecessoribus praedictorum fratrum videtur patere ex eorum regula' ${ }^{75}$ John comes to the same conclusion: 'Cum igitur ex regula Carmelitae obligentur ad silentium, et ad vitam eremiticam... patet evidenter, quod fuerint successores praedictorum, se conformiter habentes ad ipso [sic] ${ }^{76}$ Kedar contrasted these accounts by contemporaries of Ribot with Thomas Scrope's more bald statement a hundred years later: 'Quod autem ista intelligenda sint de Carmelitis patet ex eorum regula per quam obligantur ad silentium, et ad sigillattim habitandum per cellas separatas', arguing that Bernard and John were referring to 'Palestinian anchorites who preceded the Carmelites' rather than to the Carmelites themselves, whereas Scrope simply labelled any hermits on the mountain Carmelites. ${ }^{77}$ Given that both John and Bernard, like Ribot, accepted the Elianic succession, the Rule of John of Jerusalem and the continuity of the order from the prophets to the Frankish period, this distinction seems one of semantics. All three thought that the Rule of St Albert was merely confirming a way of life that could be traced back not just to Aimery's reform of the twelfth century, but to the original 'Rule' of John of Jerusalem, and beyond that to Elijah and the minor prophets. Albert's only contribution, in their accounts, was to acquire papal confirmation for the order, and thus to bring it into the mainstream of canonical legislation.

The evidence of Gerard of Nazareth for the same general type of community described by the Rule of St Albert on the Black Mountain, in Judaea and Galilee from the I I 20 s onward strengthens the assumptions of later Carmelites that their order predated Albert's Rule. But, if hermits

\footnotetext{
76 'Informatio circa originem': Speculum Carmelitanum, i. 168.

${ }^{76}$ John of Hildesheim, 'Dyalogus': Speculum Carmelitanum, i. I52.

77 Thomas Scrope, 'Chronicon': Speculum Carmelitanum, i. 175; Kedar, 'Gerard of Nazareth', 57-8.
} 
were living on Mt Carmel at the time Gerard was writing, why did he not mention Mt Carmel at all? Gerard's hermits were all active in those regions with which he was familiar from his own career or upbringing: Galilee, Antioch and Jerusalem. It is possible, though unlikely, given his familiarity with the ecclesiastical affairs of his day, that he may not have known of similar eremitical settlements on Mt Carmel contemporary with his work, $c$. I I 20-6o. It is also possible that Gerard did not write about hermits on Mt Carmel because they were Greek Orthodox rather than Frankish monks. As we have seen, the northern summit and slopes of the mountain, around the cave of Elijah, and the spring of Elijah, where the ruins of St Elisha were to be found, seem until the settlement of 'B. and the other hermits' to have been the preserve of the Greeks. This made it easy for Ribot to claim the continuous occupation of Mt Carmel, and, by skipping lightly over the topography, to annex the Orthodox communities to the later Frankish foundation.

Despite the implausibility of Ribot's use of Aimery of Antioch to bring together Orthodox and Latin hermits into a single order, Greek influence on the early Carmelites cannot be ruled out. Ribot's impression of an order in which Franks joined an existing Greek tradition is exemplified by the figure of Cyril of Constantinople, the putative author of the letter of Eusebius of the Black Mountain. The Cyril used by Ribot to transmit information about the 'Byzantine period' of the order was, by the fourteenth century, honoured as the third prior-general of the Carmelites. John Bale, relying on Ribot and others, says that Cyril was born in Constantinople and began his career in Asia Minor, where he converted the 'king of Iconium' to Christianity. He was Manuel Comnenus's legate to Pope Alexander III, then in I 165 was summoned in a vision to Armenia, where he preached for a further ten years, baptising the king. He then seems to have joined the community of Mt Carmel, and ruled as prior from I 208 until his death in $1234 .{ }^{78}$ This biography is repeated in slightly different form by Ribot's editor Daniel, according to whom Cyril was summoned to Mt Carmel by the Blessed Virgin after becoming convinced of the truth of the Latin theological position on the Holy Spirit and disputing with the patriarch of Constantinople. ${ }^{79}$ The Centuriators' account of Cyril concentrates on the conversion of the Armenian king

${ }^{78}$ Bodl. Lib., ms Selden Supra 4 I, fo. 15 or. Bale also mentions a Greek follower of Cyril, Theolophorus, who was apparently sent by the order to Joachim of Fiore.

${ }^{79}$ Speculum Carmelitanum, i. 4 . Some explanation was obviously needed by the Carmelites for the presence of a Greek as prior-general. The procession of the Holy Spirit had, by the mid-twelfth century, become the major theological issue dividing Greeks and Latins, and the story of the dispute with the patriarch may be based on the historical figure of Hugo Etherianus, who participated in the Council of Constantinople in 1166. The Armenian interlude must refer to the attempts by Manuel Comnenus to reunite the Greek and Armenian Churches, and to the partial conversion of Armenia to papal obedience in the thirteenth century. Zimmermann accepted Cyril's existence as genuine but not his Byzantine origins: Monumenta, i. 295. 
(giving the year II $8 \mathrm{I}$ ), and supplies verses by the fifteenth-century Carmelite humanist Baptista Mantuanus about Cyril's later career in Sicily. ${ }^{80}$

It is unlikely that Ribot simply invented the character of Cyril. The other 'primary sources' for the De institutione, John, bishop of Jerusalem and William of Sandwich, were real figures, even if they left no writings. ${ }^{81}$ Cyril may have been a Greek monk sufficiently prominent - or obscure - in his day to inspire later legends. He is unlikely to have been active over the whole period from the I 160 s to I 234, and it would be useful to know in which half of this period to place him: was he associated with a preCarmelite Orthodox community on Mt Carmel, or with the development of the order after the regulation of St Albert and the papal confirmation of 1226 ? If the latter, then he provides evidence of a Greek monk becoming a member of a Latin Order, or possibly even of a joint Latin-Orthodox foundation. The Rule itself gives no clues: it is terse and uncontroversial, betraying no Orthodox influence at all, though St Basil could have been a model as easily as St Benedict. The Carmelite Order, indeed, was to acknowledge Basil as the inspiration of St Albert's Rule. ${ }^{82}$ Properly, Albert's canons are not a Rule by a typikon, because they applied at the time of writing to a single community rather than an order, but this was as common for foundations in eleventh- and twelfth-century France or Italy (such as Fonte Avellana or Obazine) as in the east. The question of possible Orthodox influences on the early history of the Carmelite Order demands fuller attention from historians, particularly in the light of the revival of Orthodox monasticism in Palestine reported by pilgrims such as John Phocas. ${ }^{83}$

Ribot was writing an apologetic rather than a historical chronicle. His use of history, however, influenced later Carmelites like Bale, and, through Bale, the Protestant Centuriators. His skilful blend of historical figures like Gerard of Nazareth and Patriarch Aimery with obscurer monks who could form the material for hagiography, like Berthold, Brocardus his successor and Cyril of Constantinople, assured for the order a history that could be linked to the central Christian experiences of crusading and pilgrimage and form part of general Christian aspirations for the Holy Land. Yet there is an irony in the Centuriators' scouring of Bale's Catalogus for information on the Carmelites, for by this time Bale's original purpose in collecting historical material had changed. In the

${ }^{80}$ Matthias, Duodecima centuria, 1610 .

${ }^{81}$ For John, see Le synaxaire éthiopien, ed. and trans R. Basset and others (Patrologia Orientalis i. 1907), 603. He was bishop of Jerusalem 386-417: G. Graf, Geschichte der christlichen arabischen Literatur, i, Vatican 1944, 337. William of Sandwich was priorprovincial for the Holy Land at the fall of Acre, and is mentioned by name in a bull of Honorius Iv: Bullarium Carmelitarum, i, Rome 1715, 35-6.

${ }^{82}$ Constitutions des Frères de Notre Dame du Mont Carmel faites l'année 1357, ed. AntoineMarie de la Présentation, Marche 1915, 12.

${ }^{83}$ Phocas, Descriptio, PG cxxxiii. 949-56. In general see Jotischky, 'Breath of the dove', $165-80$. 
ANDREW JOTISGHKY

Catalogus he still used the same historical methodology, looking beyond the medieval period to establish a line of succession from the very early Church to his own day, but now, rather than proving the venerable antiquity of the Carmelite Order, he was arguing passionately for the faithfulness of the Reformation to the origins of Christianity. 